Wood Science and Technology 42(8):691-698 December 2008

\title{
Introducing Undeinked Old Newsprint As A New Resource of Electrical Purposes Paper
}

$$
\text { By }
$$

Tamer Y. A. Fahmy ${ }^{*}$, Fardous Mobarak and Magda G. El-Meligy

Cellulose and Paper Department, National Research Center, Sh. El-Tahrir, Dokki, Cairo, Egypt.

*Correspondence to: Dr. Tamer Y. A. Fahmy, Cellulose and Paper

Department, National Research Center, Sh. El-Tahrir, Dokki,

Cairo, Egypt.

E-mail: drtamer_y_a@yahoo.com 


\section{$\underline{\text { ABSTRACT }}$}

This work introduces, for the first time worldwide, undeinked recycled old newsprint as a new resource of electrical purposes paper. Impregnation of undeinked recycled old newsprint paper, by linseed oil, enhances the breaking length of paper and remarkably improves its electrical properties i.e. the dielectric constant increases greatly and the a.c. conductivity decreases significantly due to impregnation. It was found that the electrical properties of the undeinked old newsprint paper and its linseed oil impregnated counterpart, are close to the electrical properties of paper made from the more expensive virgin wood pulps and their linseed oil impregnated counterparts. Using the undeinked pulp is privileged than using the deinked pulp; because eliminating the deinking step saves money, time, and reagents. In addition, eliminating the deinking step improved the breaking length of paper. Electron dispersive $\mathrm{X}$-ray elemental analysis (EDX) was used to investigate the undeinked and deinked pulps for residual elements originating from the printing materials. EDX was correlated to the slight differences in electrical properties of paper made from undeinked and deinked pulps. However, impregnation was able to overcome these slight differences. It was shown that improvement in electrical properties, due to impregnation, is sustained at elevated temperatures. 


\section{Introduction:}

There is a wide range of new and conventional uses for paper in electrical purposes. Examples of these applications include: insulations for integrated circuits in electronic devices, insulations for radio wires, insulations for electricity cables and transformers, or as dielectric paper for various types of capacitors.

Cellulose possesses an exceptionally high dielectric constant. However, the dielectric constant of paper is much lower. This is due to the high percentage of air voids and pores in paper. Air has a comparatively low dielectric constant. Therefore, to raise the dielectric constant of paper sheets it is a common technique to replace -to some extent- the air in paper voids by oils, resins ..etc. The impregnating material should possess greater dielectric constant than air (greater specific inductive capacity than air). The dielectric constant of impregnated paper is a complex function of the electrical properties of individual cellulose fibers, paper, and the impregnating material.

The dielectric constant of cellulose ranges from 6 to 8.1, while that of paper ranges from slightly greater than 1 to 2.5 . The dielectric constant of typical insulating paper ranges from about 1.2 to 4 (Willis and Raju 2003; Mobarak et al. 1999 a, b; Mohsen and Mobarak 1996; Mobarak et al. 1996 a, b; Casey 1962). 
In a series of research articles, the authors and others threw light for the first time on the electrical properties of paper made from agricultural residues pulps, and their linseed oil impregnated counterparts. (e.g. rice straw paper, cotton stalks paper and bagasse paper). Commercial wood papers were, also, investigated for the sake of comparison. Some, of the investigated agricultural residues papers, showed electrical properties close to wood papers, or even superior to it (Mobarak et al. 1999 a, b; Mohsen and Mobarak 1996; Mobarak et al. $1996 \mathrm{a}, \mathrm{b})$. This motivated the authors to expand the studies, on electrical properties of paper, to other cheap and abundant raw materials. Recycled old newsprint is an abundant raw material that is cheaper than virgin wood pulps. In addition, finding new uses for recycled paper and increasing the rate of recycling is beneficial to the environmental efficiency of the whole paper industry (Bobu and Ciolacu 2007). Therefore, in recent unpublished work, the authors introduced -for the first time- deinked recycled old newsprint as a new resource of electrical purposes paper. It has shown great success. This encouraged the authors, in the present work, to further expand their studies to undeinked recycled old newsprint. Using undeinked pulp saves money, time and reagents; by eliminating the deinking step. The effect of linseed oil impregnation, on the electrical properties of undeinked recycled old news print paper, will be investigated. The effect of elevated temperatures, on the electrical p 4 of 18 tp 
properties of the impregnated and unimpregnated paper sheets, will be also studied in this work. Electron dispersive X-ray elemental analysis (EDX) will be used to investigate the undeinked and deinked pulps for residual elements originating from the printing materials (e.g. inks, stabilizers, etc). EDX will be correlated to any differences in electrical properties of paper made from undeinked and deinked pulps. 


\section{$\underline{\text { Material and Methods: }}$}

- Waste paper used: -

The waste paper used in this work was composed of uncolored and colored newsprints in equal ratios.

- Recycling of the undeinked old newsprint, and paper sheet making: -

An efficient recycling method for old colored newsprint was implemented. This method was previously established by the authors and others (El-Meligy and Ibrahim 2001). However, in the present work, the deinking step was eliminated.

The paper sheets were prepared according to the SCA standard, using the SCA - model sheet former (AB Lorenzen and Wetter).

- Analyses of the undeinked recycled newsprint:-

We have carried out analyses for the undeinked recycled newsprint. The results of the analyses are reported in Table $\mathbf{1}$.

- Scanning Electron microscopy, and energy dispersive X-ray elemental analysis $(\mathrm{EDX}):-$

The scanning electron micrograph of the undeinked recycled newsprint is shown in Figure 1. The scanning electron microscopy and EDX were conducted by Jeol JXA-840 A Electron Probe Micro analyzer. - Electrical properties of the prepared paper sheets: -

The dielectric constant (É), and the alternating current conductivity ( $\sigma$ a.c.) were calculated using the following formulas respectively: 
$\hat{E}^{\prime}=\left(\mathrm{C} / \mathrm{E}_{\mathrm{o}}\right) \times(\mathrm{d} / \mathrm{A}), \sigma$ a.c. $=(\mathrm{d} / \mathrm{A}) \times(1 / \mathrm{R})$, where $\mathrm{C}$ is the capacitance of the sample in Farads, $\mathrm{E}_{\mathrm{o}}$ is the capacitivity of vacuum $(8.85 \mathrm{E}-12 \mathrm{~F} / \mathrm{m})$, $\mathrm{d}$ is the sample thickness in $\mathrm{m}, \mathrm{A}$ is the area of the used gold electrode in $\mathrm{m}^{2}, \mathrm{R}$ is the sample resistance in ohms. $\mathrm{C}$ and $\mathrm{R}$ were measured using computerized Hioki 3532-50 LCR Hi Tester. 


\section{$\underline{\text { Results and Discussion: }}$}

The undeinked old newsprint was recycled, and paper sheets were prepared from it as mentioned in the experimental part.

Some of the undeinked recycled paper samples were impregnated with linseed oil using dipping technique then hanging the impregnated paper sheets to dry in air at room temperature. Electrical properties of the unimpregnated and impregnated paper sheets were investigated at room temperature $\left(30^{\circ} \mathrm{C}\right), 70^{\circ} \mathrm{C}$, and $110^{\circ} \mathrm{C}$, for alternating current frequencies up to $20000 \mathrm{~Hz}$.

Table 2 shows the comparison between the electrical properties of the unimpregnated and impregnated paper sheets at a.c. frequencies of $200 \mathrm{~Hz}, 2000 \mathrm{~Hz}$, and $20000 \mathrm{~Hz}$ (at the different investigated temperatures).

At a.c. frequency of $200 \mathrm{~Hz}$, the dielectric constant increased due to impregnation. This was true at all investigated temperatures. At room temperature $\left(30^{\circ} \mathrm{C}\right)$, the dielectric constant of unimpregnated sheets was 2.94, while that of the impregnated sheets increased to 4.29. Thus the percentage increase in dielectric constant, due to impregnation, was 45.91\%. The a.c. conductivity decreased due to impregnation. This was true at all investigated temperatures. At room temperature $\left(30^{\circ} \mathrm{C}\right)$, the a.c. conductivity of unimpregnated paper sheets was 1.14 E-10 (1/ohm.cm), while that of the impregnated paper sheets p 8 of 18 tp 
decreased to 0.88 E-10 (1/ohm.cm). Thus the percentage decrease in a.c. conductivity, due to impregnation, was $22.81 \%$.

At a.c. frequency of $2000 \mathrm{~Hz}$, the dielectric constant increased, also, due to impregnation. This was true at all investigated temperatures. At room temperature $\left(30^{\circ} \mathrm{C}\right)$, the dielectric constant for unimpregnated sheets was 2.73 , while that of the impregnated sheets increased to 3.91 . Thus the percentage increase in dielectric constant, due to impregnation, was 43.22\%. The a.c. conductivity decreased due to impregnation. This was true at all investigated temperatures. At room temperature $\left(30^{\circ} \mathrm{C}\right)$, the a.c. conductivity of unimpregnated paper sheets was 2.34 E-10 (1/ohm.cm), while that of the impregnated paper sheets decreased to $1.62 \mathrm{E}-10$ (1/ohm.cm). Thus the percentage decrease in a.c. conductivity, due to impregnation, was $30.76 \%$.

At a.c. frequency of $20000 \mathrm{~Hz}$, the dielectric constant increased, also, due to impregnation. This was true at all investigated temperatures. At room temperature $\left(30^{\circ} \mathrm{C}\right)$, the dielectric constant for unimpregnated sheets was 2.38, while that of the impregnated sheets increased to 3.46 . Thus the percentage increase in dielectric constant, due to impregnation, was $45.37 \%$. The a.c. conductivity decreased due to impregnation. This was true at all investigated temperatures. At room temperature $\left(30^{\circ} \mathrm{C}\right)$, the a.c. conductivity of unimpregnated paper sheets was 4.82 E-10 (1/ohm.cm), while that of the impregnated paper sheets p 9 of 18 tp 
decreased to $2.96 \mathrm{E}-10$ (1/ohm.cm). Thus the percentage decrease in a.c. conductivity, due to impregnation, was $38.59 \%$.

It is worth mentioning that the dielectric constant decreased gradually by increasing the a.c. frequency. Starting from about $10000 \mathrm{~Hz}$, the dielectric constant was not affected by increasing the a.c. frequency i.e it became virtually constant. This was true for the unimpreganated and impregnated paper sheets, at all investigated temperatures.

EDX Investigations: The EDX charts of the undeinked and deinked pulps are shown in Figures $2 \mathrm{a}$ and $2 \mathrm{~b}$ respectively. The EDX was used to investigate both pulps for traces of residual elements originating from the printing materials (e.g. inks, stabilizers ..etc). The undeinked pulp showed a greater number of residual elements in its EDX chart, as compared to the deinked pulp. The deinked pulp showed only $\mathrm{Cu}, \mathrm{Zn}$ and $\mathrm{Ca}$. While the undeinked pulp showed $\mathrm{Cu}, \mathrm{Zn}, \mathrm{Ca}, \mathrm{Fe}, \mathrm{K}, \mathrm{Ti}, \mathrm{Al}$ and $\mathrm{Si}$.

In recent unpublished work, the authors investigated the electrical properties of the deinked recycled paper, and its linseed oil impregnated counterpart. The present work shows that the a.c. conductivity of the undeinked recycled paper is higher than that of deinked recycled paper by about $5-7 \%$. The dielectric constant of the undeinked recycled paper is shown to be lower than that of deinked recycled paper by about $1.5-3 \%$, at the investigated temperatures and a.c. frequencies. This may be attributed to the presence of greater number of conducting elements in p 10 of 18 tp 
undeinked pulp, as compared to deinked pulp. However, linseed oil impregnation succeeded to overcome these differences. The a.c. conductivities and dielectric constants, of impregnated undeinked and impregnated deinked recycled paper, appeared to be very close, with a difference of about only $\pm 1 \%$, at the investigated temperatures and a.c. frequencies.

Breaking length of the undeinked recycled paper sheets increased greatly due to impregnation by linseed oil. The breaking length of the unimpregnated paper sheets was 1416 meters, while that of the impregnated paper sheets increased to 2954 meters. The percentage increase in breaking length due to impregnation was $108.61 \%$. Linseed oil is a drying oil. When it is exposed to air it solidifies to give a strong film. This is the reason for the increase in the breaking length of the impregnated paper sheets. The atmospheric oxygen attacks the double bonds of the polyunsaturated fatty acids present in linseed oil. This leads to cross-linking of the fatty acids chains, and hence solidification of the oil (Parker 1997).

In recent unpublished work, the authors investigated the breaking length of the deinked recycled paper, and its linseed oil impregnated counterpart. The present work shows that the breaking length of undeinked recycled paper sheets is more than that of deinked recycled paper by about $8-10 \%$; because deinking may lead to some decrease in 
paper strength. This is true for both unimpregnated and impregnated sheets.

Density of the undeinked recycled paper sheets increased due to impregnation. The density of unimpregnated paper sheets was $0.264 \mathrm{~g} / \mathrm{cm}^{3}$, while that of impregnated paper sheets increased to $0.483 \mathrm{~g} / \mathrm{cm}^{3}$. The percentage increase in density due to impregnation was $82.95 \%$.

\section{Conclusions:}

The present work introduces for the first time worldwide undeinked recycled old newsprint -an abundant raw material which is cheaper than virgin wood pulps- as a new resource of electrical purposes paper.

Linseed oil impregnated undeinked recycled old newsprint paper, produced in this work, finds its use as specialty electrical purposes paper. Finding new uses for recycled paper and increasing the rate of recycling is beneficial to the environmental efficiency of the whole paper industry.

Impregnation of undeinked recycled old newsprint paper, by linseed oil, enhanced the breaking length of paper and remarkably improved its electrical properties i.e. the dielectric constant increased greatly and the a.c. conductivity decreased significantly due to impregnation. Even at elevated temperatures, the improvement in electrical properties of paper, due to impregnation, was sustained.

Electron dispersive X-ray elemental analysis (EDX) was used to investigate the undeinked and deinked pulps for residual elements p 12 of 18 tp 
originating from the printing materials (e.g. inks, stabilizers, etc). EDX was correlated to the slight differences in electrical properties of paper made from undeinked and deinked pulps. However, impregnation was able to overcome these slight differences.

The present work shows that the electrical properties of both the undeinked and deinked recycled old newsprint papers and their linseed oil impregnated counterparts, are close to the electrical properties of paper made from the more expensive virgin wood pulps and their linseed oil impregnated counterparts. However, using the undeinked pulp is privileged than using the deinked pulp; because eliminating the deinking step saves money, time, and reagents. In addition, eliminating the deinking step improved the breaking length of paper. 


\section{References:}

Bobu E, Ciolacu F (2007) Environmental aspects of enzyme deinking. Professional Papermaking 4(1): 6-13

Casey JP (1962) Pulp and Paper. Interscience Publishers Inc., New York

El-Meligy MG, Ibrahim MM (2001) Deinking and reuse of old colored newsprint. Journal of Scientific and Industrial Research 60 (8): 649-654

Mobarak F, Mounir M, Mohsen F, Ali AFH (1999a) Studies on the electrical properties of agricultural residues paper I: Electrical properties of cotton stalks and wood papers. Cellulose Chemistry and Technology 33 (3-4): 321-331

Mobarak F, Mounir M, Mohsen F, Ali AFH (1999b) Studies on the electrical properties of agricultural residue papers II: Electrical properties of rice straw paper and its blends with cotton stalks and wood. Cellulose Chemistry and Technology 33 (5-6): 513-525

Mohsen F, Mobarak F (1996) Effect of impregnation with linseed oil on electrical properties of cotton stalks and wood paper. Journal of Scientific and Industrial Research 55 (7): 511-515 Mobarak F, Mounir M, Ali AFH (1996a) Effect of temperature on electrical properties of cotton stalks and wood paper impregnated by linseed oil. International conference on chemistry and technology of fibers and textiles, December 10-12, Cairo, Egypt

Mobarak F, Mounir M, Ali AFH (1996b) Effect of temperature on electrical properties of rice straw and wood paper impregnated by linseed oil. International conference on chemistry and technology of fibers and textiles, December 10-12, Cairo, Egypt

Parker SP (1997) Auto-oxidation. McGraw-Hill Encyclopedia of Science \& Technology, 8th edn. McGraw-Hill, New York

Willis HL, Raju GG (2003) Dielectrics in Electric Fields. Power Engineering Series, Marcel Dekker, Inc., New York, Basel. 
Table 1

Analysis of the undeinked recycled newsprint

\begin{tabular}{|c|c|}
\hline Alphacellulose \% & 57.9 \\
\hline Hemicellulose \% & 19.0 \\
\hline Lignin \% & 22.5 \\
\hline Ash \% & 0.9 \\
\hline
\end{tabular}




\section{Table 2}

Electrical properties of unimpregnated and impregnated paper sheets, made from undeinked recycled newsprint, at a.c. frequencies of $200 \mathrm{~Hz}, 2000 \mathrm{~Hz}$, and $20000 \mathrm{~Hz}$ (at room temperature $30^{\circ} \mathrm{C}, 70^{\circ} \mathrm{C}$, and $110^{\circ} \mathrm{C}$ )

\begin{tabular}{|c|c|c|c|c|c|c|}
\hline \multirow[t]{2}{*}{ a.c. frequency $(\mathrm{Hz})$} & \multicolumn{2}{|c|}{200} & \multicolumn{2}{|c|}{2000} & \multicolumn{2}{|c|}{20000} \\
\hline & $\begin{array}{c}\text { Unimpregnated } \\
\text { paper sheets }\end{array}$ & $\begin{array}{l}\text { Impregnated } \\
\text { paper sheets }\end{array}$ & $\begin{array}{l}\text { Unimpregnated } \\
\text { paper sheets }\end{array}$ & $\begin{array}{l}\text { Impregnated } \\
\text { paper sheets }\end{array}$ & $\begin{array}{c}\text { Unimpregnated } \\
\text { paper sheets }\end{array}$ & $\begin{array}{l}\text { Impregnated } \\
\text { paper sheets }\end{array}$ \\
\hline Dielectric constant at $30^{\circ} \mathrm{C}$ & 2.94 & 4.29 & 2.73 & 3.91 & 2.38 & 3.46 \\
\hline Dielectric constant at $70^{\circ} \mathrm{C}$ & 2.87 & 4.27 & 2.76 & 3.88 & 2.36 & 3.44 \\
\hline Dielectric constant at $110^{\circ} \mathrm{C}$ & 2.84 & 4.26 & 2.73 & 3.88 & 2.36 & 3.45 \\
\hline a.c. conductivity at $30^{\circ} \mathrm{C}(1 / \mathrm{ohm} . \mathrm{cm}) \mathrm{E}-10$ & 1.14 & 0.88 & 2.34 & 1.62 & 4.82 & 2.96 \\
\hline a.c. conductivity at $70^{\circ} \mathrm{C}(1 / \mathrm{ohm} . \mathrm{cm}) \mathrm{E}-10$ & 1.06 & 0.73 & 2.11 & 1.34 & 4.70 & 2.38 \\
\hline a.c. conductivity at $110^{\circ} \mathrm{C}(1 / \mathrm{ohm} . \mathrm{cm}) \mathrm{E}-10$ & 1.04 & 0.72 & 2.08 & 1.32 & 4.68 & 2.37 \\
\hline
\end{tabular}

$\mathrm{p} 16$ of 18 tp 


\section{Figure 1}

The scanning electron micrograph of the undeinked recycled newsprint (at 250X)

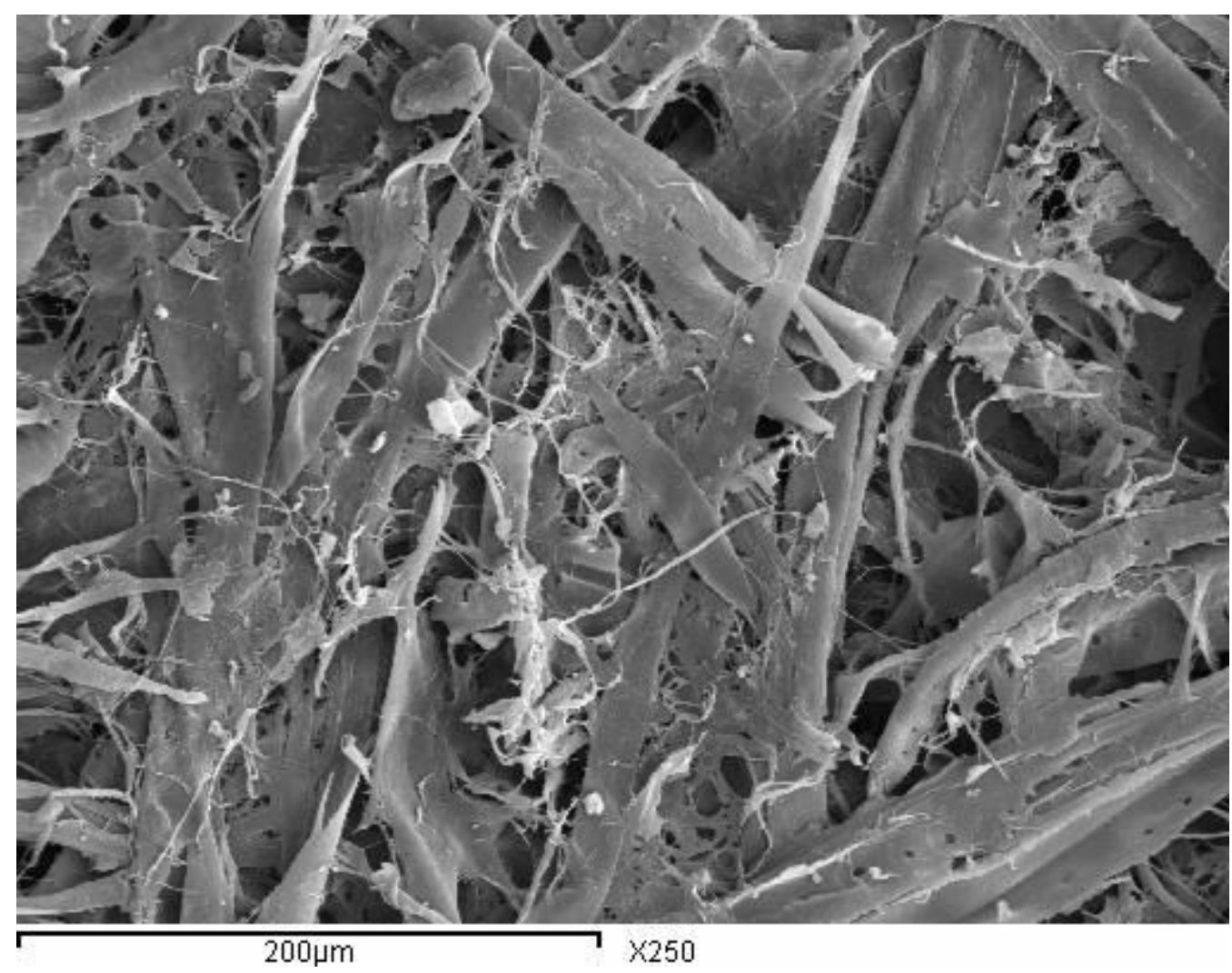

p 17 of 18 tp 


\section{Figure 2a}

The EDX chart of the undeinked recycled newsprint

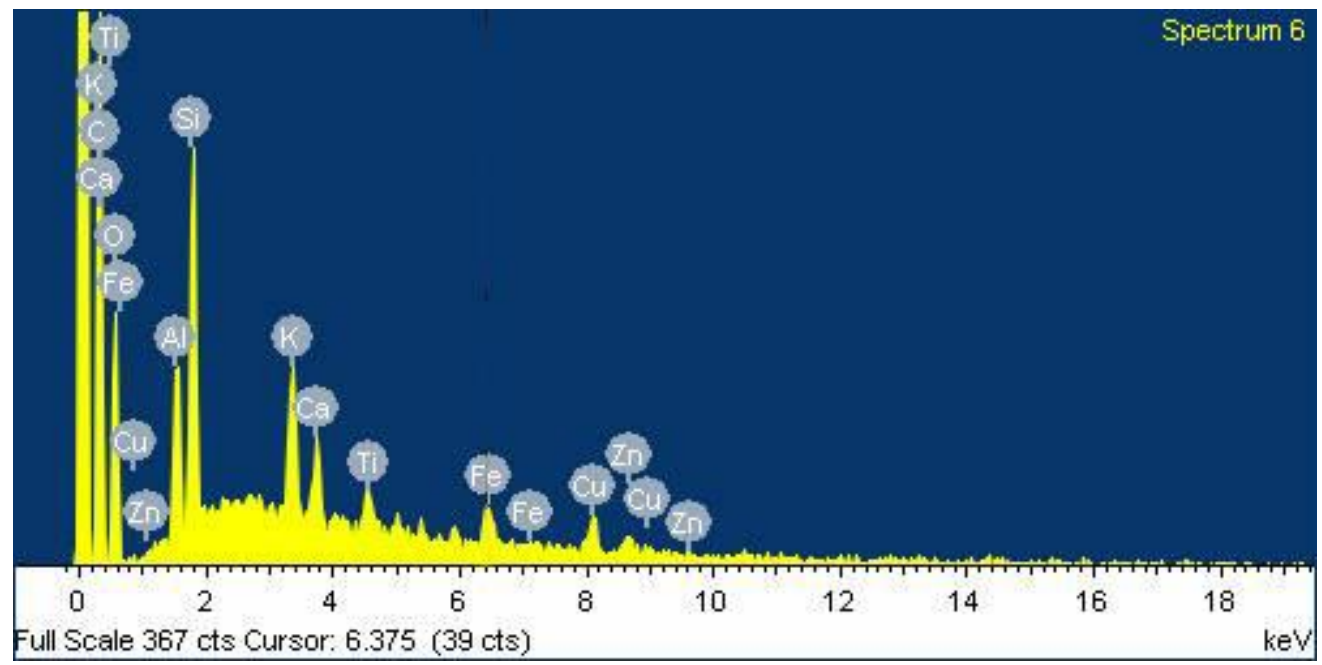

Figure 2b

The EDX chart of the deinked recycled newsprint

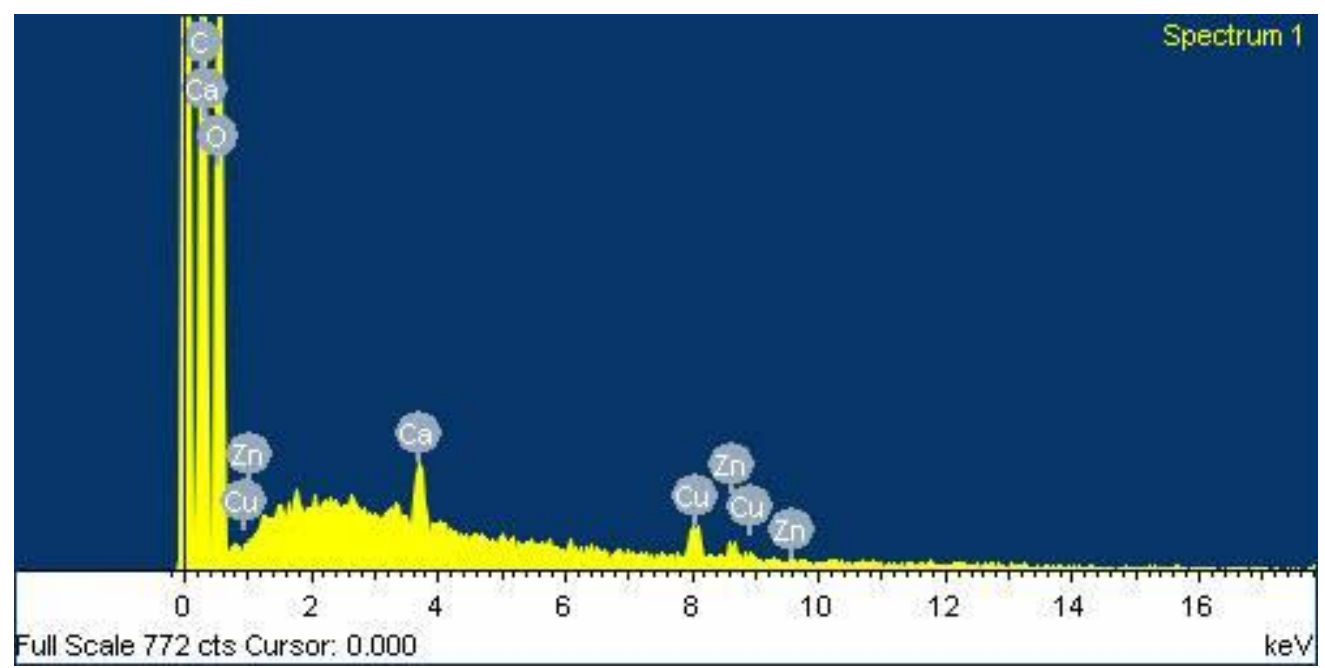

p 18 of 18 tp 